\title{
Selective mutism and shyness. Differential diagnosis and strategies supporting child development
}

\begin{abstract}
Dorota Podgórska-Jachnik, Selective mutism and shyness. Differential diagnosis and strategies supporting child development. Interdisciplinary Contexts of Special Pedagogy, no. 30, Poznań 2020. Pp. 125-149. Adam Mickiewicz University Press. ISSN 2300-391X. e-ISSN 2658-283X. DOI: https://doi.org/10.14746/ikps.
\end{abstract} 2020.30.07

The article deals with the problem of differential diagnosis of extreme reticence or selective speech in a child, categorised as selective mutism and shyness. Selective mutism is an increasingly recognized disorder among preschool and school children. It manifests itself functionally in the sphere of speech and communication, but in relation to the anxiety factor. As an anxiety disorder, it is categorised in the latest medical classifications ICD-11 and DSM-5, and therefore, primarily psychological or psychiatric therapeutic intervention could be expected. The specificity of the pathomechanism of selective mutism, however, requires interdisciplinary activities, with a room for a speech therapist, a special pedagogue (e.g. at a public school as a supporting teacher), any other pedagogue working with the child (educator, teacher of integrated classes, subject teacher), other specialists (therapist pedagogue, physiotherapist), as well as the parents. The speech therapist may play a special role in the diagnosis of mutism in the conditions of inclusive education, as he will probably be the first specialist who will receive a child who is not speaking or very taciturn at a public school. In the article, the diagnosis of selective mutism is associated with the differential diagnosis of shyness, which may not be treated as a disorder, but only a certain personality trait, but with incompetent pedagogical support in everyday educational practice it can lead to more serious difficulties, including logophobia and mutism. The diagnosis of mutism requires specialised therapeutic 
measures, but with the awareness of the differences in the situations of a shy child and a child with mutism, it is worth learning some supportive strategies that are useful in both cases.

KEY WORDS: selective mutism, shyness, diagnosis, development support, education support

\section{Introduction}

In education practice, mainly at preschools and primary schools, one can see the problem of non-speaking or extremely taciturn children ever more frequently. The scale of this problem is, on the one hand, an obvious consequence of the concept of inclusive education in the system, thanks to which many disabled children and those with special education needs, caused by other factors, undertake education in public schools. Most disabled children and many with other development disorders experience diverse kinds of communication difficulties, noticed and solved by special educators, however, they may constitute a significant barrier in the education process for teachers not specifically prepared, and constitute a significant challenge in terms of efficient paedagogical and therapeutic support. The issue is not just limited to the question of how to communicate with a child who does not speak (depending on the cause and mechanism, these may be quite different compensation strategies), but in general - how to recognise the core of the child's difficulties, including, how to differentiate between the different possible disorders so as to pick the right form of support, and - very importantly - how not to cause them to deepen through own errors. One of the reasons of being silent - despite the retention of the capacity to communicate by speech - is selective mutism. Teachers, particularly preschool and early education teachers, meeting such cases frequently exhibit helplessness ${ }^{1}$, as they see a communication barrier

1 This knowledge stems from the author's experience as teacher-consultant for special education needs at the voivodeship teacher development centre in Zgierz, 
on the one hand, on the other noticing the education potential in these children that is difficult to develop. A frequent reaction is also failure to believe in the long-term persistence and consequence of the child in their silence, and explaining this behaviour by shyness. And mutism is related to shyness somewhat, however, should not be mistaken for it, the more so that shyness is not a disorder. In both cases, however, the pupil might need certain forms of aid. This is why the differentiation between these two categories and possible support strategies form the subject of this article.

\section{The reticent and the non-speaking child}

In teacher observations, both mutism and shyness will shine through e.g. in reticence, sometimes bordering on not speaking, and sometimes - as in case of mutism - the teacher may not even see a speaking child (the child may perhaps be speaking to one teacher, but not to others). Children - as well as adults - differ in terms of speaking activity, sometimes intensely. Moreover, reticence must not always be assessed as being negative, even though our culture most commonly expects participation in social situations through discussions and expression. For adults, the "talkativeness" of preschoolers is usually an expected indicator of correct cognitive development, the more so that they first bind this activity to so-called external speech, which, while in fact fulfilling a different developmental role, is for the beholder a form of externalisation of what the child thinks, how they perceive the world and own activity. A similar role is played by the experience of endless questions of preschoolers, typical for the age. An indicator of correct development is also using speech in social interactions. Hence, a child's reticence may disconcert their parents, who see more negative effects of this situation than positive ones. The latter are basically limited to the

Poland, where she, among others, conducted method workshops on work with children with selective mutism for five years. 
fact that a child speaking little seems to be good, polite, non-competitive, not causing trouble (Chmyłko-Terlikowska, 2018). Negative effects may include: lack of joy from contact with children and adults, limited emotional experiences, limited experiences in playing together with peers - risk of disturbances in socialisation, limited development of social skills, limited activity, in particular social activity, lack of friends, loneliness, lower independence, barriers against participation in education situations at preschool and at school, and in the end, risk of reduction of education opportunities.

Research by Mary A. Evans showed that records of a series of 15 classes with seven reticent children and seven not exhibiting these limitations indicated that reticent children not only spoke more less frequently, but also used less complicated speech than their peers, used limited code (most commonly referring to the "here and now"), their statements were shorter and less diverse topically. Differing from their peers, they did not treat questions as invitations to broaden the subject. The author concluded based on observations that both disconcert as well as subtle linguistic setbacks may contribute to worse discourse competences, as exhibited by reticent children (Evans, 1987). The research is quite dated, hence, it is unknown, to what extent they consider the causes of reticence of the individual children, including their tendencies of mutism.

At times, due to limitations in verbal expression, but also prompting signals of expectation of greater activity by the environment, a child may show signs of frustration or even nervous disorders (Warchał and Warchał, 2012), e.g. in the form of body tension, rigidity, physical blockages, signs of motor anxiety, lack of natural freedom, etc., negative emotions, such as anxiety, shame, sense of threat, sadness, limited non-verbal communication, limited facial expression and avoidance of eye contact, limited emotional expression (excess control and restraint in laughter or crying reactions), with even certain physiological symptoms related to the somatisation of difficulties and anxieties (e.g. as digestive disorders - stomach pains, failure to defecate - constipation, unwillingness to relieve oneself at an unknown place). This does not mean, however, that 
this applies to any reticent child - these are not characteristic of such children. These are rather issues that must be considered as potential ones. Among factors coexisting with low speaking activity (including silence) as well as other behaviour described as reticent ${ }^{2}$, passive or solitary-passive, the following can be named

- anxiety, social anxiety, negative social experiences (including past trauma) (Chen et al., 2006);

- low self-esteem, low confidence, low sovereignty, dependence on others (Chen et al., 2006);

- perfectionism (Hewitt et al., 2011, Ołdakowska-Żyłka and Grąbczewska-Różycka, 2017, Ołdakowska-Żyłka, 2017);

- particular emotional needs developed under the influence of anxiety, and learned modes of their satisfaction (achievement of the feeling of safety or attracting attention of the environment through silence); inattentive or overly attentive (overbearing) environment (conf. Miernik-Jaeschke, Namysłowska, 2016).

Even a short analysis of these factors indicates deep social conditions for the tendency to reticence, even if this is ultimately conditions on the interaction of external factors and the child's internal dispositions. Many cases of mutism also show the fundamental role of insufficiencies or grave irregularities in the social environment of the child in the etiology (WHO, 2008, acc. to: Grąbczewska-Różycka, 2017), even though genetic preconditions tend to be ever more commonly indicated (Grąbczewska-Różycka, 2017).

\section{Selective mutism - disorder definition and classification}

The prevalence of selective mutism is not unequivocally determined, however, estimates point to a gradual increase of its prevalence (Johnson and Witgens, 2018). The sources from the years 1996-2001 quoted by Urbaniak (2008) show that epidemiological

2 The adjective "reticent" means speaking little, unwilling to talk, be quiet, not eager to talk about things/ others, shy but also terse, withdrawn or discrete. 
factors of mutism lie between $0.2 \%$ to $0.1 \%$. Later studies show differentiation of prevalence: the population of children and adults shows a factor of ca. $0.02 \%$, but the population of children being treated psychiatrically - 0.2\% (Namysłowska, 2012). Selective mutism is more frequent in younger children - ca. $0.7 \%$ (one child per 140 aged up to eight years) than in older ones - ca. $0.18 \%$ (one child in 550), even if Johnson and Witgens (2018) estimate that this still indicates high probability of emergence of at least one pupil with mutism in every primarily school and in the majority of secondary (above-primary) schools.

On the functional level, mutism may be treated as extreme reticence (even though people with this disorder can talk quite a lot in an environment they accept, most commonly home). Selective mutism is a disorder entailing blockage of verbal communication, with the adjective "selective" completing the term indicates that it only shines through in certain situations (Bystrzanowska, 2018; Johnson and Wintgens, 2018; Urbaniak, 2018 et al.) - most commonly at preschool or school, but it may also show only in certain (pre)school situations or only with respect to certain persons (even though one may rather say that [a child] would only exhibit the will to communicate verbally with certain people).

In terms of the ICD-10 classification of diseases, selective mutism is included in social functioning disorders, beginning most commonly in childhood or during youth. This indicates agreement on the lesser role of constitutive factors, including organic damage, and a more important role of acquired experiences. The diagnostic criteria of selective mutism (F 94.0) cover per the ICD-10 (2008):

- speech expression and comprehension by the child reduced to within twice the standard deviation;

- documentable inability to speak in certain situations, in which it is expected of the child, despite speaking in other situations.

The disorder is not explained by the lack of knowledge of spoken language required in social situations, in which the inability to speak emerges, with the persistence time of silence exceeding four weeks (ICD-10, 2008). According to ICD-11 as well as DSM - this is 
at least a month, whereby it must be noted that the assessment of the child's behaviour should not be limited to their first month at school. This is an adaptation period, and one must account for withdrawn behaviour in children, even high reticence, while not describing these as disorders outright. The persistence time of selective mutism as a disorder is counted in months, however, these may be years. ICD-11 (2020) additionally indicates the significance of its effects: the diagnosis of mutism should be made if it significantly impacts educational achievements or social communication.

Selective mutism is excluded in the ICD as a speech expression disorder - it is hence not developmental dysphasia or expressive aphasia - and speech comprehension disorders - it is not the result of innate hearing perception disorders. ICD-11 also stresses that the disorder may not be diagnosed in case of a speech impediment conditioned upon bilingualism, when a different language is spoken at school than at home (ICD-11, 2020).

It is worth noting that treating selective mutism as a social functioning disorder is not the only possible approach to this problem.

ICD-10 (2008)

\section{V-Psychological and behaviour disorders}

(F94) Disorders of social functioning with onset specific to childhood and adolescence

(F94.0) Selective mutism
ICD-11 (2020)

\section{Mental, behaviour \\ or neurodevelopmental disorders}

Anxiety or fear disorders

(6B06) Selective mutism

\section{Exclusions:}

- Schizophrenia (F20.-)

- Temporary mutism related to separation anxiety in young children (F93.0)

- Comprehensive development disorders (F84.)

- Specific speech and language development disorders (F80.-)

Fig. 1. Changes in the placement of selective mutism among other disorders in ICD-10 and ICD-11 (source: own work, based on ICD-10, 2008 and ICD-11, 2020) 
In fact, despite mutism not being treated as a speech disorder, it is a disorder in communication; and the most recent etiology-based views clearly place it among anxiety-related disorders (ICD-11). This is a significant change compared to ICD-10 (fig. 1).

The latest DSM-5 classification similarly includes selective mutism among anxiety disorders. It is worth noting that changes in ICD-11 and DSM-5 are related to the trend towards classification simplification, but also stem from the inclusion of new knowledge about the underlying disorders, primarily in terms of etiology and mechanisms. Hence, the latest placement of mutism is based primarily on anxiety as the key causal and solidifying factor for the social reaction of silence.
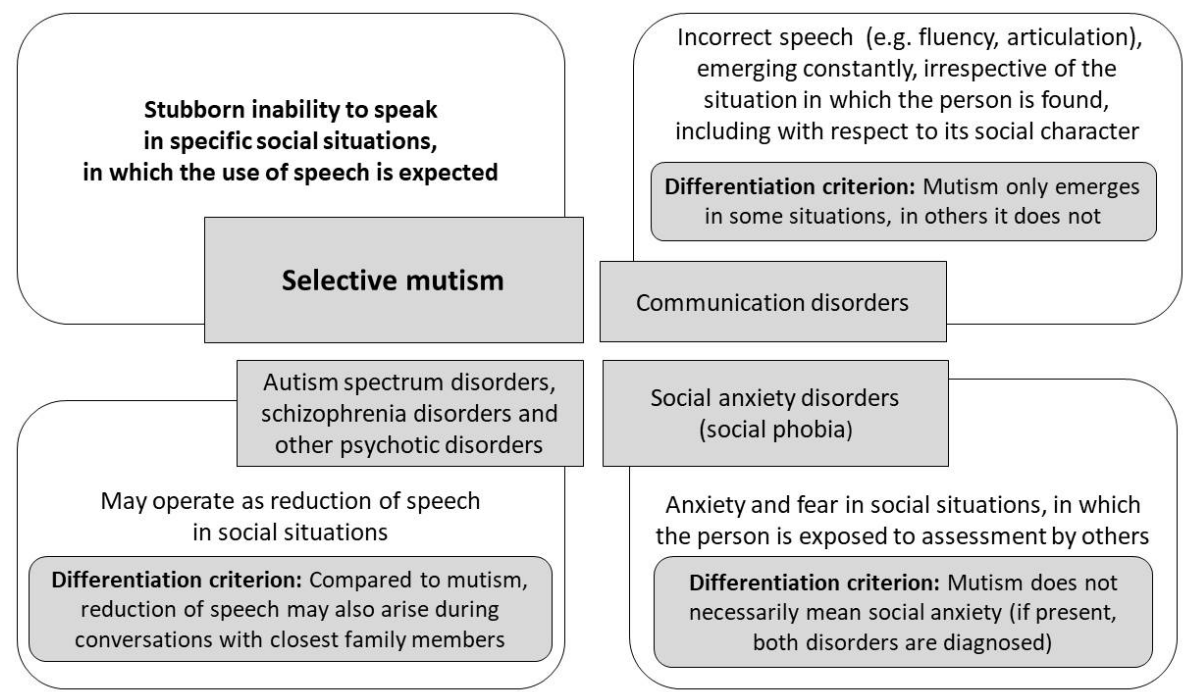

Fig. 2. Differential diagnosis of selective mutism per DSM-5 criteria (source: own work, based on First, 2016, p. 213)

On the basis of DSM-5 diagnostic criteria, the basics of the differential diagnosis, covering other disorders with symptoms most similar to selective mutism, were developed. Selective mutism per 
DSM-5 is differentiated from communication disorders (disorders in terms of speech and its usage), the jointly listed autism spectrum disorders, schizophrenia and other psychotic disorders, as well as social anxiety disorders, also called social phobia (fig. 2). The differentiation between these disorders is very subtle, and the diagnosis is difficult. Moreover, diagnoses must not necessarily always be disjointed, as e.g. social anxiety disorders may accompany selective mutism, and because anxiety itself is the main factor in the etiology of mutism, this means that beside social anxiety, it may also be caused by other types of anxieties.

\section{Mutism and shyness}

Shyness is considered to be not only a main factor in communication difficulty, but as a certain biological, temperamental predisposition for mutism. Beside shyness, these can also be: bashfulness, social withdrawal, worries or negativism (Steinhausen and Juzi, 1996; Stein, Rapin and Yapko, 2001). Steinhausen and Juzi (1996, acc. to: Kearney, Vecchio, 2006) link mutism in their work to general shyness, in particular also with social anxiety, even though it might also be accompanied by opposing behaviour (Paez and Hirsch, 1998, acc. to: Kearney, Vecchio, 2006). In general, these conditions are quite complicated, as beside temperamental components - predispositions towards mutism - certain social behaviour patterns may also be found in the child's family, and related to the already mentioned anxiety disorders (social withdrawal of the parents or other close family members, their intense worrying, phobias and social phobias, anxiety behaviour, difficulties related to separation anxiety), reinforcing the child's biological predispositions. A third component are evocative situations related to changes in the environment that are significant and emotionally important to the child, acting as stressors (fig. 3). For this reason, mutism is frequently observed in reaction to changes in the environment, a relocation, a new school or preschool, but also arguments in the family or divorce, 
emergence of siblings, illness or death in the family, etc. (Urbaniak, 2008). It is believed that for all these conditions, the core of mutism is a neurotic reaction to social factors - the presence of other people and interaction pressure.

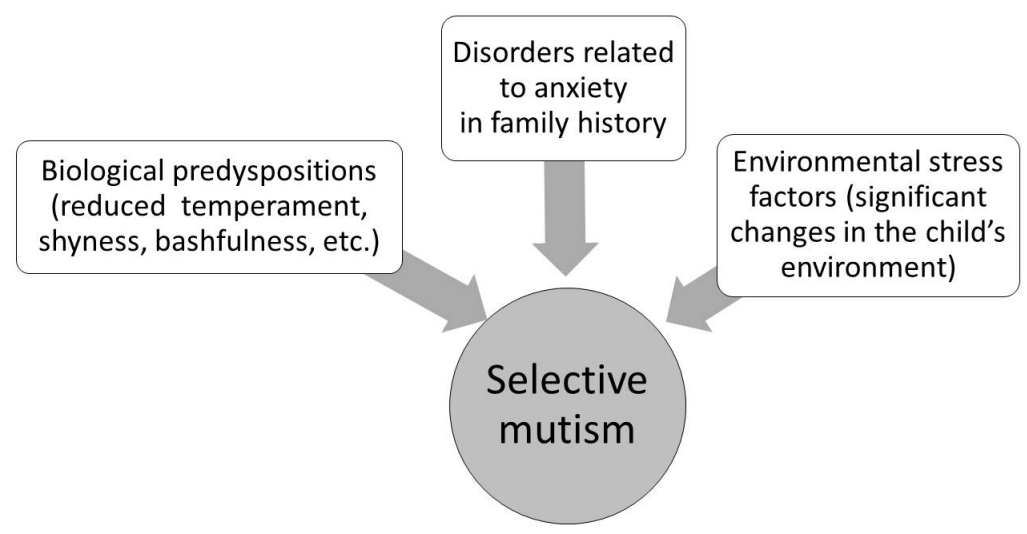

Fig. 3. Conditions for selective mutism and its relations to shyness (source: own work, based on Stein, Rapin and Yapko, 2001, p. 927; Urbaniak, 2008, p. 457)

To achieve an even fuller image considering diverse interpretations of the psychological causes of autism, fig. 4 presents etiological factors. The analysis by Janowska indicates that the main psychological causes of mutism may be interpreted within the context of a few theories, as should be considered in different therapeutic concepts for this disorder. In systemic theory, primarily the (overly) high dependence of the child on the parents is worth noting, as being due to their excess control. In behavioural theory, attention is drawn to limiting influence by situations new and atypical to the child in terms of the sympathetic nervous system, responsible for the body's mobilisation. Speech blocks are a certain form of self-conrol in the face of actual or anticipated anxiety. In the integrated development theory, there emerges a more complex solidification of the pattern of unconscious avoidance behaviour of parents as 
related to language deficits. Shyness would in this case be a combination of biological and psychological factors. The third group of audiological and neurobiological causes is worth noting. Even though, as was already indicated on the basis of medical classification, the elimination of hearing damage is a criterion, however, certain disorders of auditory processing co-existent with language deficits may also play a certain role in the etiology of mutism (Janowska, 2018).

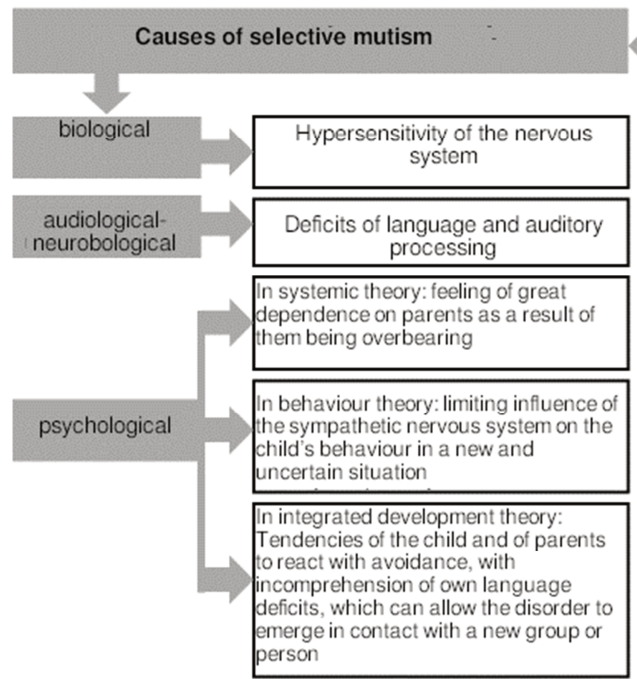

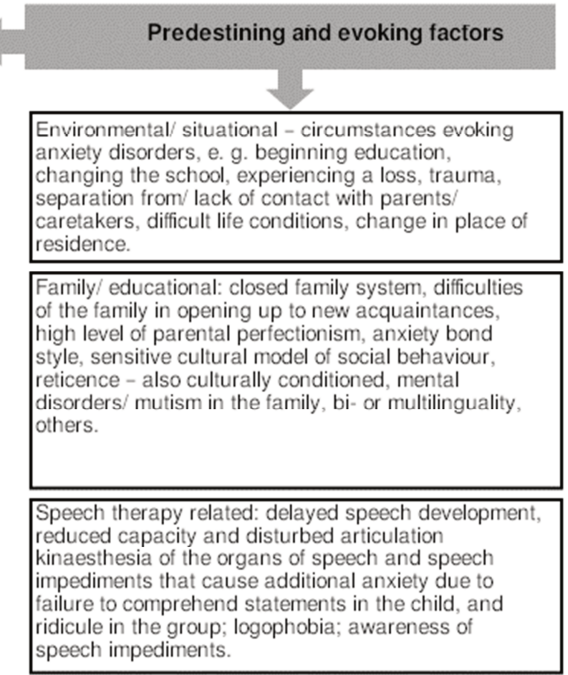

Fig. 4. Etiological factors of selective mutism (own work based on Janowska, 2018, pp. 49-50)

Interesting and extensive is also the classification of predestining and evocative factors as suggested by the author, covering a long list of environmental, educational and speech-related issues (Janowska, 2018). This opens up a path to thinking of areas of therapeutic support for a child with selective mutism using education therapy, sociotherapy, psychotherapy and, quite importantly, speech therapy. Considering the instrumental character of speech-related 
competences, one might even indicate speech therapy to be key, in particular as it may and should also cover psychotherapeutic and educational activity.

Special therapy is treated as the required standard in the aid provided to the child with diagnosed selective mutism (without this help, the problems may only solidify), however, it is not necessary to subject every reticent and shy child to therapy. Despite the prevalence of similar symptoms, shyness is not a disorder. For this reason, it is not the subject of a clinical differential diagnosis, even though it should be differentiated from mutism. Despite it not being a disorder, however, it still is a behaviour issue in the child's upbringing, in particular in terms of its activity at a preschool or school. At times, a child's shyness - or even just seeming shyness is more of a problem for parents, expecting the descendant to be incredible, than for the child themselves. Such a situation is also worth looking at, as excessive expectations of parents, out of line with the child's capacities, can be the cause of future problems with the child unable to cope with parental demands. It can also indicate preexisting problems along the line parents-child, tied to the lack of the acceptance of the latter. In most situations, however, it is not necessary to initiate therapy of a child exhibits shyness - perhaps with the exception of extreme shyness related to strong anxiety reactions disorganising their functioning. Shyness, however, may cause multiple psychological burdens related to discomfort and blocks in interpersonal relations. Beside the feeling of embarrassment, shame and fear - an emotional component similar to the one present in the etiology of mutism - the shy person also sees that their problems are visible to others. This reinforces the dislike for social exposure, hence, the vicious cycle of anxiety. Even if therapy is not required, shy children can be helped to develop their communication and social skills, to improve their self-esteem, and hence, they can be aided to develop satisfying social relations. The differentiation between mutism and shyness will be necessary in terms of the diagnosis of different education needs and the possibility of support for the child within a preschool or school facility. 
Monika Andrzejewska collected apt and useful criteria to differentiate mutism and shyness for the educational practice. A list of these criteria is presented in the following diagram (fig. 5).

MoneCTIVE MUTISM cohesive functioning image

Fig. 5. Differences between selective mutism and shyness (source: own work based on Andrzejewska, 2013, p. 63)

\section{Educational and therapy procedure in selective mutism}

Despite silence being the main symptom, therapies utilised in mutism are aimed at a different area than speech: Work with anxiety, sometimes with trauma, with the child's unfulfilled emotional needs. Relaxation techniques are applied, self-regulation is taught for emotionally burdening situations, as well as desensitisation of the child in social situations. Independence, self-esteem, self-confidence are developed and improved (Bystrzanowska, 2018; Chmyłko-Terlikowska 2018; Ołdakowska-Żyłka and Grąbczewska-Różycka, 2017; Urbaniak, 2008). The therapeutic process should include 
the parents as well (Johnson, Wintgens, 2018): This applies to both education coaching and the relationship with the child. ${ }^{1}$

As part of the first meta-analsis of research results concerning the effects of evidence-based treatments, conducted in 2002, the usability of diverse forms of behaviour therapy - including neobehaviour therapy, the social role of teaching as well as cognitivebehaviour therapy - was noted - however, with efficacy of mixed methods and other approaches not being excluded - grounds to assess them were missing (Stone et al., 2002). The 2016 metaanalysis found efficiency of psychosocial interventions related to gradual exposure to situations requiring verbal communication (Hua and Major, 2016). Reports are available of good results obtained through non-specific auxiliary therapies, e.g. kynotherapy/speech kynotherapy (Grochowska, 2016).

The strategy of work with a child with selective mutism, suggested by Maggie Johnson and Alison Wintgens - the authors of a uniquely thorough and practically very useful monograph called Selective Mutism, with the well-deserved title: Resource Manual (The Polish translation was published in 2018) - fits in with the cognitive-behaviour-based exposure therapy. Assuming that the patient confrontation with the source of their anxiety should take the form of gradual flooding, this should occur through systematic desensitisation under graded exposure. A second simultaneous therapeutic process line is the shaping of the target behaviour pattern with gradual stimulus fading. The authors stress that "the method is very useful for working with mutism, because it is the stimulus, and not the behaviour of the individual, that is subject to gradual changes. They are encouraged to speak if the situation turns uncomfortable, and when they speak, a new person approaches and joins

${ }^{1}$ Bystrzanowska (2018) indicates an anxiety style bond with parents in children with mutism, and in the family - an anxiety-based and sensitive cultural model. However, the author believes that this does not give rise to looking for pathologies in the family. Parents frequently seek help, expect support to help their child. Educational and therapy support for parents stems both from their needs and from the logic of support for the child through support for family relations. 
in" (Johnson, Wintgens, 2018, pp. 222-223). The authors have developed a range of special techniques and tactics useful for mutism therapy, suitable for the child's needs and forms of contact tolerated by them. This technique, called sliding in, remains in line with the presented exposure-based therapy; it allows gentle progress by small steps, from acceptable forms of social interaction (with a trusted person), to gradually ever broader relations and new situations, but also e.g. such tactics (informal strategies used in everyday work with the child) as using colleagues and parents as intermediates, the usage of questions, the five-second technique (waiting for a verbal or non-verbal reaction, without taking over speaking for the child) ${ }^{2}$ or the triangle technique (initiating conversation e.g. with a peer, a newly-met child, in the presence of a partner or trusted caretaker). The entire book holds a plethora of hints that allow both for solutions to difficult emergency situations, but primarily for a long-term (mutism therapy regrettably requires time and patience) and comprehensively planned and implemented strategy to help the child, covering both therapeutic as well as education effort, with the help of a (here: speech) therapist, teachers and, naturally, parents. The therapy - in line with the presented assumptions - encompasses a plan to increase the difficulty level, covering social situations structured by closeness, number of witnesses, group size, place of interaction, but also the type of engagement in group work and the related form of communication (Johnson, Wintgens, 2018). There is no consent as to the use of alternative communication methods with children with selective mutism: most therapists believe that it should not be introduced, as this discourages the child from communicating verbally. Johnson and Wintgens do not take such a rigorous approach, as they believe that this should be dependent on the di-

${ }^{2} \mathrm{~A}$ short guide to this technique, developed on the basis of the approach of Johnson (as well as guides on other techniques) may be found at mutyzm.org.pl (in Polish): Poradnik dla rodziców dziecka z mutyzmem wybiórczym (zasada 5 sekund), http://www.mutyzm.org.pl/wp-content/uploads/wiedza/Poradnik-dla-rodzic\%C3 \%B3w-dziecka-z-mutyzmem-wybi \%C3\%B3rczym-materia \%C5\%82y-szkolenioweMJ.pdf [access: 1.10.2020]. 
agnosed needs of the child. There are situations when stripping them of such a communication option means taking away their sole form of expression, hence, it could be likened to preventing the child from speaking. With certainty drawings, graphics, icons, certain components of non-verbal communication may form transitional communication aids, but it should be only temporary and limited in time. The majority of children rather do not need this. However, it is possible to use non-verbal support in the form of gestures or facial expressions.

One could also perhaps explain the presence of a speech therapist for therapy, since it was stated that mutism should not be treated as a speech disorder, but as an anxiety disorder. This is substantiated by any clear functional relationship between verbal communication and the emotional sphere in case of this disorder, and if its character would suggest the need of an interdisciplinary intervention, then the character of the disorder itself gives rise to the need for a discrete intervention, without the child being overborne by multiple therapists. In general, there are no contraindications for the head therapist to be a psychologist or therapeutic educator they would naturally need to be materially prepared in terms of the specifics of therapy of a child with mutism - however, the speech therapy aspects indicated in the mutism etiology (Janowska, 2018; see also table four in this text), as well as auxiliary speech therapy techniques useful for the core therapy suggest a speech therapist for this role. The speech therapist works with the voice and articulation, develops verbal communication, simplifying the transition from non-verbal communication, working out the easiest techniques to initiate sound and speech emissions and effective fluent speaking techniques, they "acquaint" and "desensitise" the child to be able to receive their own voice (work with recordings, the camera, microphone, etc.), they support learning and reading, etc. (Johnson, Wintgens, 2018).

They thus improve the child's self-esteem, expanding their communication competences. Naturally, all components of therapy should work in concert, including teacher-parent cooperation. 
Teachers implement the currently developed communication methods in school practice, without exerting pressure and not accelerating the course of therapy (hence the need for close cooperation), only using e.g. the auxiliary tactics described above. The parents also have a grand role to play in the reduction of anxieties, in improvement of self-esteem, the development of good relations and the creation of a safe space to practice the new communication skills, best intertwined with daily activities. Sadly, the research by Janowska (2018) shows that not all parents of children with selective mutism get any sort of indications from therapists. Those who have acquired them, listed the following recommendations:

- discussion of the child's problems when parents play with the child,

- no pressure on the child (concerning verbal communication),

- encouragement of parents to broaden knowledge on selective mutism,

- encouraging parents to act to improve the child's self-esteem,

- reading therapeutic stories,

- inviting peers to visit the child at home,

- keep a motivation table,

- contract further consultations, e.g. psychiatric ones,

- provide the child with a feeling of security,

- praise the child,

- reinforce the child in their right to make errors and mistakes in action (Janowska, 2018, p. 42).

\section{Supporting the shy child}

As was already described, shyness is not a disorder, but a certain personality and behaviour trait, and, as such, is not valuated, even though some (e.g. Kozak, 2007) treat it as a form of interpersonal relation disorder. Shyness can be perceived positively, however in most cases it suggests persevering reductions of opportunities in diverse aspects of activity, and, as a result - reduction of life 
opportunities, not only with respect to the school or professional career, but also in terms of opportunities to enter into intimate relations with others (Zimbardo, 2000). This is why shy children may require support, encouragement, motivation, but primarily acceptance of who they are. Literature contains little hints on working with shy children (Gładyszewska-Cylulko, 2007; Sosin, 2014; Zabłocka, 2008) or youths (Hamer, 2000), even though their behaviour sometimes remains akin to behaviour of children or youths with mutism. Even though the majority does not require therapy, and, moreover, many adults - even those well-known - openly confess that they "used to be shy children", certainly need support, and some hints may be used in this regard - some process tactics used in mutism therapy.

The fundamental, similar strategies of action both in shyness as well as mutism (even though mutism must include therapy), are:

- the child's development in various spheres, the development of interests and skills,

- development of the awareness of one's strengths,

- reduction of anxiety and development of self-confidence,

- not enforcing verbal communication of the child is clearly not ready for it - especially in a situation of social exposure and/ or in new situations.

In one of few Polish publications on work with shy children (nota bene published on a website devoted to mutism, but under the banner of the Polish Mutism, Shyness and Anxiety Therapy Centre, further confirming the unity of these behaviour categories observed by practising therapists), Anna Resler confirms from the point of view of the practical therapist that shyness in children is a frequent cause of visits at psychological practices. With grand professional culture, the author replies: "During initial visits, the psychologist handles "shyness shyly", meaning, as if they did not know it, slowly attempts to comprehend its significance for the child's functioning, speaks less, listens more, tries to see what it strips the child of, and what it provides the child with. Even if it is easy to respond to the question about losses (for parents), it is harder to think about the gains" (Resler, 2013). I believe that this response is the 
core of the diagnostic approach to all developmental difficulties of the child (I consciously refrain from using the term "disorders"), as the first duty of the diagnostic specialist is not only to "cover" the criteria check list of symptoms, but to look holistically at the child's situation, and search for an answer about the function of the disconcerting behaviour. Resler continues: "It is the task of the specialist to differentiate the issue, with which a client comes in, be it shyness or anxiety, shyness, depression, limited social skills or the experience of violence, or perhaps something else. The objective is to aid the child and its family irrespective of the name of the difficulties. At times, to name it and repeat it with the child present may in fact exacerbate the problem" (Resler, 2013). The author suggests the following educational strategies that should be implemented by the parents, best in cooperation with the child's teachers:

- self-esteem improvement - through common play, sport, praise, indication of strong suits; gradation of difficulties is significant in order to achieve cohesion between the child's efforts and the assessment of effects;

- awakening of interests and skills - leading to the evocation of cognitive curiosity, the feeling of competences, as a result reduction of the feeling of anxiety;

- becoming aware of the prevalence of shyness among people and the possibility of overcoming it - organisation of support groups, sharing own experiences;

- free time management;

- modelling social behaviour - the parents can be an example of openness in social relations, initiative in getting to know new people, making day to day conversations with other random people (if the parents also find it difficult, it is easier to develop changes together);

- the parent as a model of expression and indication of emotions, confessing to such feelings as anxiety or anger, realistic expectations with respect to self, coping with errors and mistakes - these can also be the components of the common remodelling of the family communication style; 
- discussing the problem without judging the child, consulting them, gentle encouragement to overcome shyness - the child should not receive any message that they are worse or not accepted due to the shyness (conf. Resler, 2013).

As shyness frequently accompanies mutism as well (Stone, 2002), and the behaviour functional profile is similar, worth considering are options of such educational direction of parents with selective mutism. Moreover, all these recommendations are useful in the education of any child, hence, no mistake can be made if parents are encouraged to such reflections and activities.

The above described materials for educational and therapeutic work with shy children can be useful in school work, especially amended by therapeutic literature, e.g. the book for younger children authored by Beth Bracken and Jennifer Bell Too shy for show and tell or the youth novel by Sarah Morant (2018) Timide. The issue of shyness sometimes finds its way to various forums and blogs that also might be used when working with shy people. Such an interesting place on the Polish internet is e.g. the forum niesmialosc.net (it is rather a place for adult users, although many entries may be useful for work with younger people), or the blog by Madame Polyglot. The latter's author, Sandra, describing herself as a teacher of German, Italian and English and trainer of teachers - writes: "I'm certainly not having it easy going through life :) But I feel completely free in situations that would only terrify me twenty or even ten years ago. (...) This blog is mainly about language learning and I believe that in this regard, shyness also plays an important role" (https://madamepolyglot. $\mathrm{pl} /$ niesmialosc/). These are just examples of sources of knowledge about what one can do with their shyness, to be used in therapeutic and educational work.

Completely different is the website entirely devoted to shyness and support work for shy people maintained by the United Statesbased psychotherapist Renée Gilbert, entitled "Shake your shyness". Beside psychological texts on shyness, the website contains interesting presentations on famous people, celebrities, describing their own experiences with shyness, life suggestions, hints for adults, 
teachers, and many more materials as well as a multitude of useful links to other websites, articles, literature. To abridge information about this interesting website to the topic of the present paper, I shall only quote selected advice by Gilbert, worth using in the classroom, which are a good amendment of the tactics and hints of Johnson and Witgens (2018). The psychotherapist provides e.g. the following advice to teachers of shy children:

- Normalise shyness and present it in a positive light: compare shy children with other shy children that grew up to be famous adults: "I think you're going to be a great movie star, like Tom Hanks. He used to be really shy!"); speak about great leaders, inventors, artists, politicians who confess to having been shy at some point in their lives (this is served by the Shy Celebrities area from the portal).

- Make regular contact with the child. Gilbert believe that shy children often fall into areas of inattention, and the farther they fall, the more difficult it is for them to comprehend attention if they are its objects. It is hence important to make regular yet natural contacts with shy children - every day, during every lesson - with a short comment, question or smile. The key is making contact in such a way so that it proceeds naturally: remain in contact and not distinguish the child (turn to the other children in a similar fashion).

- Provide shy children with tasks to perform so that they could gain motivation to work, contribute to the group and have a reason to interact - with peers. However, adapt the social interaction level of tasks to the tolerance level of the child, bringing the tasks in order according to increasing difficulty.

- Comment on their successes and show/present their work. This, however, requires a lot of tact, as the majority of shy children require attention yet are scared. Praise must be conveyed with care, e.g. as a hit and run: convey the praise and quickly move to another topic. It means that the pupils should not be provided with sufficient time to turn and notice the specific student. Avoid longer eye contact if this is not com- 
fortable for the child (this does not mean, however, that such contact should not be sought at all) (Gilbert, 2011).

These are just some examples. Gilbert notes that teachers should also see a different problem: The necessity to notice bullying, which shy children are more susceptible than others. They are bullied more easily as the risk is greater that they will not allow themselves to complain to adults. Bullying in class is a difficult subject - the solution can be aided through rare books for children on the subject, e.g. Dręczyciel w klasie (Bully in Class, 2016), Powiedz komuś (Tell Someone, 2004) or Dobre i złe sekrety (Good and Bad Secrets, 2019) by Elżbieta Zubrzycka, as well as ROBUSD educational materials devoted to the problem of school violence within the context of special education needs (Pyżalski, Roland, 2010).

\section{Summary}

Selective mutism is a disorder that is ever more frequently being diagnosed in children. It is characterised by shining through in speech and communication, but due to its causes and mechanism, it is treated as an anxiety disorder. On the observation level, a child with mutism is considered to be reticent or non-speaking, and the place where this most frequently manifests itself is the preschool or school. This may significantly reduce the child's education opportunities, with co-existing negative emotional components (anxiety) being a serious problem requiring therapeutic support but also suitable educational handling. On the clinical level, selective mutism is differentiated from other disorders: communication disorders, autism spectrum disorders, schizophrenia and other psychotic disorders, as well as social anxiety disorders (social phobia). On the level of educational practice, mutism must be differentiated from shyness, which cannot be treated as a disorder, but which also blocks social activity and activity related to learning. A shy child frequently requires support, and certainly - special attention by the teacher, in certain situations - therapy. The article indicated some opportu- 
nities to help children with mutism and shy children. Therapy of children with mutism requires special knowledge on the procedure in case of this disorder, in case of shyness - most commonly empathic understanding of the behaviour and needs of the child by the educator is sufficient. Support work may utilise some techniques, strategies and tactics proven to be effective in work with children with mutism. On the educational support level, activity in both cases may be similar. Support for children with mutism requires most often, however, therapeutic intervention - one cannot hope for mutism to "go away by itself", as may be the case frequently, and as is the case often with shyness. With extremely intense shyness - this does not always come to pass without negative psychological effects. The basis for the proper choice of the personalised action strategy should be a thorough differential diagnosis.

\section{References}

Andrzejewska M. (2013), Jak pomóc dziecku lub uczniowi z mutyzmem selektywnym? „TRENDY. Internetowe Czasopismo Edukacyjne” no. 4; pp. 62-65; [online], http:/ / www.bc.ore.edu.pl/Content/579/T042013\%2C+M.+Andrzejewska.pdf [access: 23.09.2020]

Bracken B., Bell J. (brw), Tomek mały jest nieśmiały. Wydawnictwo NATULI, Szczecin. Bystrzanowska M. (2018), Mutyzm wybiórczy. Poradnik dla rodziców, nauczycieli i specjalistów. Oficyna Wydawnicza „Impus”, Kraków.

Chen X., Chen H., Dan L., Li W., Zhengyan W. (2015), Early Childhood Reticent and Solitary-Passive Behaviors and Adjustment Outcomes in Chinese Children. "Journal of Abnormal Child Psychology" no. 43(8), pp. 1467-1473; DOI: 10.1007/s10802015-0028-5.

Chen X., DeSouza A.T., Chen H. \& Wang L. (2006), Reticent behavior and experiences in peer interactions in Chinese and Canadian children. "Developmental Psychology", 42(4), pp. 656-665; https://doi.org/10.1037/0012-1649.42.4.656.

Chmyłko-Terlikowska D. (2018), Mutyzm wybiórczy u dzieci, „Forum Logopedy” no. 24 (march), [online] https://forumlogopedy.pl/artykul/mutyzm-wybior czy-u-dzieci [access: 23.09.2020]

Evans M.A. (1987), Discourse characteristics of reticent children. "Applied Psycholinguistics", Volume 8, Issue 2, June, pp. 171-184.

Gilbert R. (2011), Shyness in the Classroom. A Page For Educational Professionals. https://www.shakeyourshyness.com/teachingshychildren.htm [access: 3.10.2020]. 
Gładyszewska-Cylulko J. (2007), Wspomaganie rozwoju dzieci nieśmiałych poprzez wizualizację i inne techniki arteterapii. Oficyna Wydawnicza "Impuls", Kraków.

Gładyszewska-Cylulko J. (2013), Psychologiczne aspekty języka i mowy, [in:] B. Winczura (ed.), Dzieci o specjalnych potrzebach komunikacyjnych: diagnoza - edukacja terapia, Oficyna Wydawnicza "Impus”, Kraków, pp. 17-34.

Grąbczewska-Różycka K. (2017), Kryteria diagnostyczne mutyzmu wybiórczego pod lupq. MutyzmPortal [online] http://mutyzmportal.pl/artykul/bledne-kololeku-w-mutyzmie-wybiorczym.htm [access: 23.09.2020].

Grochowska J. (2016), Kynoterapia jako forma wspomagania rozwoju i komunikacji dziecka. Niepublikowana praca magisterska. Zakład Pedagogiki Specjalnej i Logopedii, Uniwersytet Kazimierza Wielkiego w Bydgoszczy, Bydgoszcz.

Hamer H. (2000), Oswoić nieśmiałość: scenariusze 22 lekcji wychowawczych w gimnazjum: 17 tematów. Wydawnictwo Veda, Warszawa.

Hewitt P.L., Blasberg J.S., Flett G.L., Besser A., Sherry S.B., Caelian C., Papsdorf M., Cassels T.G., Birch S. (2011), Perfectionistic Self-Presentation in Children and Adolescents: Development and Validation of the Perfectionistic Self-Presentation Scale Junior Form. "Psychological Assessment".

Hua A., Major N. (2016), Selective mutism. "Current opinion in pediatrics". 28(1), pp. 114-120.

ICD-10. International Statistical Classification of Diseases and Related Health Problems. Rev. X, Vol. 1, WHO 2008, Centrum Systemów Informacyjnych Ministerstwa Zdrowia, Warszawa 2018.

ICD-11 for Mortality and Morbidity Statistics, Verison: 9/2020 [online], https:/ /icd.who. int/browse11/1-m/en\#/http://id.who.int/icd/entity/167946871.

Janowska P. (2018), Wsparcie edukacyjne i specjalistyczne dla dzieci/uczniów z mutyzmem wybiórczym z perspektywy ich rodziców (na podstawie badań własnych). „Edukacja” no. 4(147), pp. 33-45

Johnson M., Wintgens A. (2018), Mutyzm wybiórczy. Kompendium wiedzy. Transl. by A. Pałynyczko-Ćwiklińska, Wydawnictwo Harmonia Universalis, Gdańsk.

Kearney C.A., Vecchio J. (2006), Functional analysis and treatment of selective mutism in children. "The Journal of Speech and Language Pathology - Applied Behavior Analysis", 1(2), pp. 141-148.

Kozak S. (2007), Patologie wśród dzieci i młodzieży: Leczenie i profilaktyka. Wydawnictwo Difin, Warszawa.

Michael B., First M.D. (2016), DSM-5. Diagnostyka różnicowa. Ed. for the Polish edition: P. Gałecki, Wydawnictwo Edra Urban \& Partner, Wrocław.

Miernik-Jaeschke M., Namysłowska I. (2016), Zaburzenia lękowe u dzieci i młodzieży, „Medycyna Praktyczna”, 23th November, [online] https://www.mp.pl/pacjent/ pediatria/choroby/psychiatria/81304,zaburzenia-lekowe-u-dzieci-i-mlodziezy [access: 23.09.2020].

Namysłowska I. (ed.) (2012), Psychiatria dzieci i młodzieży. Wydawnictwo Lekarskie PZWL, Warszawa. 
Ołdakowska-Żyłka B. (2017), Błędne koło lęku w mutyzmie wybiórczym, MutyzmPortal [online] http://mutyzmportal.pl/artykul/bledne-kolo-leku-w-mutyzmie-wybior czym.htm [access: 23.09.2020].

Ołdakowska-Żyłka B., Grąbczewska-Różycka K. (2017), Mutyzm wybiórczy. Strategie pomocy dziecku i rodzinie. Wydawnictwo Difin, Warszawa.

Podgórska-Jachnik D. (2019), Wspomaganie uczniów z zaburzeniami mowy, języka i komunikacji w edukacji włączającej. „Edukacja” no. 4(147), pp. 8-21.

Poradnik dla rodziców dziecka z mutyzmem wybiórczym (zasada 5 sekund), http:/ /www. mutyzm.org.pl/wp-content/uploads/wiedza/Poradnik-dla-rodzic\%C3\%B3wdziecka-z-mutyzmem-wybi\%C3\%B3rczym-materia\%C5\%82y-szkoleniowe-MJ.pdf [access: 1.10.2020].

Pyżalski J., Roland E. (ed.), Bullying a specjalne potrzeby edukacyjne - podręcznik metodyczny. WSP w Łodzi, Centrum Badan Behawioralnych Uniwersytetu w Stavanger, https://repozytorium.amu.edu.pl/bitstream/10593/5514/4/Bul lying_a_specjalne_potrzeby\%20edukacyjne.pdf [access: 4.10.2020].

Resler A. (2013), Nieśmiałość dziecka. Centrum Terapii Mutyzmu, Nieśmiałości i Lęku, https:/ / mutyzm.pl/Artyku\%C5\%82y/Nie\%C5\%9Bmia \% C5\%82o\%C5\%9B\%C4 \%87_dziecka [access: 1.10.2020].

Sosin I. (2014), ADHD i nieśmiatość: ćwiczenia i karty pracy do zajęć korekcyjno-kompensacyjnych. Wydawnictwo Dr Josef Raabe Spółka Wydawnicza, Warszawa.

Steinhausen H.C., Juzi C. (1996), Elective mutism: An analysis of 100 cases. "Journal of the American Academy of Child \& Adolescent Psychiatry", no. 35, pp. 265-288.

Stone B., Kratochwill Th., Sladezcek I., Serlin R. (2002), Treatment of selective mutism: A best-evidence synthesis. „School Psychology Quarterly”, 17, pp. 168-190.

Stowarzyszenie „Polskie Towarzystwo Mutyzmu Wybiórczego” (2018), Terapia dziecka z mutyzmem wybiórczym, [online] http://www.mutyzm.org.pl/terapia/ [access: 23.09.2020].

Urbaniak J. (2008), Dziecko z mutyzmem wybiórczym, [in:] B. Cytowska, B. Winczura, A. Stawarski (red.), Dziecko chore, niepetnosprawne, z utrudnieniami w rozwoju, Oficyna Wydawnicza „Impuls”, Kraków, pp. 455-470.

Warchał A., Warchał M. (2012), Wspótwystępowanie mutyzmu wybiorczego w zaburzeniach nerwicowych, [in:] Skibska J., Larysz D. (ed.), Neurologopedia w teorii i praktyce. Wybrane zagadnienia diagnozy $i$ terapii dziecka, Akademia Techniczno-Humanistyczna w Bielsku-Białej, Bielsko-Biała, pp. 97-106.

Zabłocka M. (2008), Przezwyciężanie nieśmiałości u dzieci. Wydawnictwo Scholar, Warszawa.

Zimbardo Ph. (2000), Nieśmiałość? Co to jest? Jak sobie z nia radzić? Warszawa, PWN. 